\title{
Pengaruh Unsur-Unsur Struktur Pengendalian Intern pada Non Performing Loan di Lembaga Perkreditan Desa Kota Denpasar
}

\author{
I Gusti Agung Listika Dewi ${ }^{1}$ \\ Ni Luh Sari Widhiyani \\ ${ }^{1}$ Fakultas Ekonomi dan Bisnis Universitas Udayana (Unud), Bali, Indonesia \\ email: agunglistika@gmail.com/Telp.082144374997 \\ ${ }^{2}$ Fakultas Ekonomi dan Bisnis Universitas Udayana (Unud), Bali, Indonesia
}

\begin{abstract}
ABSTRAK
Penelitian ini bertujuan untuk membuktikan secara empiris pengaruh unsur-unsur pengendalian intern pada non performing loan di LPD Kota Denpasar.Data yang digunakan dalam penelitian ini adalah data primer berupa jawaban kuesioner dan data sekunder berupa non performing loan LPD. Sampel yang digunakan sebanyak 35 LPD di Kota Denpasar. Pengambilan sampel menggunakan metode nonprobability sampling dengan teknik sampel jenuh. Teknik analisis yang digunakan dalam penelitian ini adalah regresi linier berganda. Hasil analisis dapat dipahami bahwa lingkungan pengendalian dan penaksiran risiko berpengaruh negatif pada non performing loan. Hal ini menunjukkan bahwa semakin baik lingkungan pengendalian dan penaksiran risiko yang diterapkan, maka menurunkan tingkat non performing loan. Aktivitas pengendalian dan pemantauan berpengaruh negatif pada non performing loan. Hal ini menunjukkan bahwa aktivitas pengendalian dan pemantauan yang dilakukan secara maksimal akan menurunkan terjadinya non performing loan.
\end{abstract}

Kata kunci: non performing loan, unsur-unsur struktur pengendalian intern

\begin{abstract}
This study aims to empirically prove the effect of internal control elements on non performing loans in LPD Denpasar City. The data used in this study are primary data in the form of answers to questionnaires and secondary data in the form of LPD non-performing loans. The sample used was 35 LPDs in Denpasar City. Sampling using nonprobability sampling method with saturated sample technique. The analysis technique used in this study is multiple linear regression. The analysis results can be understood that the control environment and risk assessment have a negative effect on non-performing loans. This shows that the better the risk control and assessment environment is applied, the lower the level of non-performing loans. Control and monitoring activities have a negative effect on non-performing loans. This shows that controlling and monitoring activities carried out optimally will reduce the occurrence of non-performing loans.
\end{abstract}

Keywords: non performing loan, elements of internal control structure

\section{PENDAHULUAN}

Lembaga Perkreditan Desa (LPD) merupakan lembaga keuangan milik Desa Pakraman yang keberadaannya berdasarkan hukum adat. LPD menjalankan fungsinya kearah peningkatan taraf hidup masyarakatdan dalam kegiatannya banyak menunjang pembangunan Desa Pakraman. LPD telah terbukti 
memberikan manfaat bagi masyarakat desa dan pembangunan desa dalam arti luas, maka keberadaaan LPD perlu dikembangkan dandilestarikan. Pemerintah Provinsi Bali memberikan perlindungan, penguatan, dan pelayanan terhadap LPD yang dikukuhkan dalam Peraturan Daerah Provinsi Bali dan Peraturan Gubernur Bali tentang Lembaga Perkreditan Desa. Peraturan Daerah tentang LPD saat ini berupa Peraturan Daerah Provinsi Bali Nomor 3 Tahun 2017 tentang Lembaga Perkreditan Desa dan Peraturan Gubernur Bali Nomor 44 Tahun 2017 tentang Peraturan Pelaksanaan Peraturan Daerah Provinsi Bali Nomor 3 Tahun 2017 tentang Lembaga Perkreditan Desa. Kegiatan utama LPD relatif sama dengan kegiatan bank, yakni menghimpun dana masyarakat dalam bentuk tabungan dan deposito, serta menyalurkan dananya berupa kredit kepada masyarakat.

Kredit adalah pinjaman yang harus dibayar kembali bersama bunganya oleh peminjam sesuai dengan perjanjian yang telah disepakati (Hasibuan, 2008:87). Kredit dapat menjadi dana bagi pihak nasabah untuk mengembangkan usahanya, maupun untuk kebutuhan konsumtif. Bagi pihak perbankan, kredit menjadi sumber pendapatan karena dari setiap kredit yang disalurkan, pihak bank akan memperoleh pendapatan bunga. Bagi pemerintah, kredit merupakan pendorong pertumbuhan ekonomi di segala sektor. Suatu fasilitas kredit juga memiliki beberapa fungsi, diantaranya untuk meningkatkan daya guna barang, meningkatkan peredaran dan lalu lintas uang, meningkatkan gairah berusaha masyarakat, sebagai alat pengendali stabilitas moneter, dan sebagai jembatan untuk meningkatkan pendapatan nasional (Rivai, 2013:200). 
Kredit merupakan sumber pendapatan terbesar dalam operasional LPD. Tingkat kredit yang disalurkan oleh LPD kepada masyarakat dapat dilihat dari perhitungan loan to deposit ratio. Rasio Loan to Deposit Ratio (LDR) merupakan rasio perbandingan antara seluruh jumlah pinjaman yang diberikan dengan dana yang diterima. Semakin tinggi LDR, maka semakin besar dana pihak ketiga yang disalurkan berupa kredit. Pengelolaan kredit harus dilakukan dengan prinsip kehati-hatian, mulai dari permohonan kredit, analisis kredit, keputusan, pencairan, pengembalian kredit dan pengawasan sedemikian rupa sehingga perkreditan dapat berjalan dengan baik. Pengawasan menjadi suatu hal yang sangat penting dan mendapatkan perhatian lebih. Penyebab utama kegagalan bank adalah kredit bermasalah (Ghazwani, 2016). Kredit bermasalah merupakan risiko bagi sektor perbankan (Norlida, 2015). Kredit bermasalah merupakan permasalahan yang dihadapi LPD dan berdampak pada kelangsungan usaha.

LPD di wilayah Kota Denpasar berjumlah 35 LPD yang tersebar di 4 kecamatan, yaitu: Denpasar Utara, Denpasar Timur, Denpasar Selatan, dan Denpasar Barat. LPD di Kota Denpasar telah memberikan kontribusi terhadap perkembangan perekonomian masyarakat setempat. Tabungan dan deposito yang dapat dihimpun LPD dari masyarakat meningkat setiap tahunnya. Peningkatan jumlah tabungan dan deposito ini menunjukkan besarnya kepercayaan masyarakat untuk menanamkan dananya pada LPD. Jumlah pinjaman yang diberikan dan non performing loan setiap tahunnya juga mengalami peningkatan. Peningkatan non performing loan atau kredit macet akan sangat berdampak terhadap kelangsungan usaha LPD. Salah satu langkah yang dapat dilakukan pihak LPD adalah 
menerapkan struktur pengendalian intern yang efektif. Pengendalian intern yang efektif dapat meminimalisir terjadinya kredit macet dan sebagai dasar kegiatan operasional yang sehat dan aman sehingga dapat dipercaya oleh masyarakat (Leonny, 2009).

Committee of Sponsoring Organization (COSO) mendefinisikan pengendalian intern adalah suatu proses yang dipengaruhi oleh manajemen dalam organisasi atau perusahaan yang digunakan sebagai dasar untuk mencapai tujuan perusahaan (Janvrin, et al, 2012). Lima komponen dari struktur pengendalian intern antara lain: lingkungan pengendalian, penaksiran risiko, aktivitas pengendalian, informasi dan komunikasi, dan pemantauan. Aktivitas pengendalian intern yang utama pada proses kredit dimulai dari tahap awal proses pemberian kredit hingga proses pengembalian kredit. Kelancaran pengembalian kredit sangat tergantung pada peranan lembaga keuangan dan kesadaran pihak debitur untuk menyelesaikan kredit yang telah disepakati. Dengan menerapkan pengendalian intern dan prosedur perkreditan secara efisien dan efektif akan menurunkan risiko kredit bermasalah.

Pengendalian intern adalah suatu proses yang melibatkan seluruh anggota organisasi, dan memiliki tiga tujuan utama, yaitu efektivitas dan efisiensi operasi, mendorong kehandalan laporan keuangan, dan dipatuhinya hukum serta peraturan yang ada (Akwaa, 2016). Pengendalian intern dapat membantu entitas mencapai target kinerja dan profitabilitasnya, serta mencegah hilangnya sumber daya yang dimiliki sehingga menjamin pelaporan keuangan yang handal (Murtanto, 2005:5). Penelitian sebelumnya pernah dilakukan oleh Ekaulandari (2013) yang 
menyimpulkan bahwa penaksiran risiko, informasi dan komunikasi, aktivitas pengendalian, serta lingkungan pengendalian berpengaruh positif terhadap efektivitas sistem pemberian kredit LPD di Kabupaten Gianyar. Penelitian yang dilakukan oleh Yasa (2013) menyimpulkan sebaliknya bahwa struktur pengendalian internal kredit berpengaruh negatif pada kredit bermasalah BPR di Kabupaten Buleleng. Hal ini berarti semakin baik penerapan pengendalian internal maka semakin rendah nilai kredit bermasalah atau NPL.

Struktur pengendalian intern merupakan sistem kontrol untuk memastikan bahwa sumber daya organisasi digunakan secara efektif dan efisien dalam pencapaian tujuan (Lelly, 2017). Pengendalian intern bertujuan untuk melindungi aset dan meminimalkan terjadinya penyelewengan, kredit macet, serta meningkatkan efisiensi dan efektivitas kerja. Penerapan pengendalian internal dalam LPD meliputi struktur organisasi yang menunjukkan adanya pemisahan tugas secara fungsional, struktur pendelegasian wewenang, prosedur pencatatan yang layak dan sumber daya manusia yang berkompeten di bidangnya. Pengendalian internal merupakan aktivitas yang dijalankan oleh manusia. Pengelolaan sumber daya manusia memerlukan cara-cara yang profesional karena penerapan terhadap pengendalian internal tidak sama antara lembaga keuangan yang satu dengan lainnya (Saraswati, 2014). Struktur pengendalian internal mewakili semua kebijakan dan prosedur dalam manajemen untuk mencapai pengelolaan yang efektif (Mihaela dan Lulian, 2012). Menurut Harmadji (2016) pengendalian internal harus diterapkan agar tidak mengakibatkan kesalahan 
(error) atau kecurangan (fraud) yang mengakibatkan adanya pelanggaran terhadap Standard Operating Guidelines (SOP).

Hasil penelitian sebelumnya menjelaskan adanya ketidak konsistenan dari hasil penelitian yang dilakukan Haninun (2011) menunjukkan hasil bahwa struktur pengendalian intern berpengaruh positif terhadap kredit bermasalah. Sejalan dengan penelitian Hasanuddin (2015) yang menunjukkan bahwa struktur pengendalian intern berpengaruh terhadap kredit macet. Penelitian Pratama (2010) menyatakan bahwa non performing loan (NPL) merupakan rasio yang digunakan untuk mengukur kemampuan lembaga keuangan dalam mengcover risiko kegagalan pengembalian kredit oleh debitur. NPL mencerminkan risiko kredit, semakin tinggi tingkat NPL maka semakin besar pula risiko kredit yang akan ditanggung.

Hasil berbeda diungkapkan oleh Dewi (2011) yang menunjukkan bahwa struktur pengendalian intern berpengaruh negatif pada kredit bermasalah. Penelitian Maharani (2014) juga menunjukkan variabel penaksiran risiko dan aktivitas pengendalian tidak berpengaruh terhadap kredit bermasalah. Penelitian lain yang dilakukan Ambaroita (2015) dan Mayura (2011) menunjukkan berpengaruh signifikan terhadap non performing loan. Pengaruh tersebut menunjukkan bahwa besar kecilnya dana pihak ketiga yang diterima tidak memengaruhi besar kecilnya tingkat kredit bermasalah.

Struktur pengendalian internal terdiri dari beberapa kebijakan dan prosedur yang dirancang untuk memberikan kepastian kepada manajemen bahwa tujuan dari perusahaan dapat tercapai. Struktur pengendalian intern adalah struktur 
organisasi, metode dan ukuran-ukuran yang dikoordinasikan untuk menjaga kekayaan organisasi, mengecek ketelitian dan keandalan data akuntansi, mendorong efisiensi dan mendorong dipatuhinya kebijakan manajemen (Mulyadi, 2010:163). Pengendalian internal adalah rencana organisasi atau metode yang digunakan untuk menjaga atau melindungi aktiva dan menghasilkan informasi yang akurat dan dapat dipercaya.

Diana dan Setiawati (2011:83) menyatakan bahwa COSO mendefinisikan pengendalian internal sebagai proses yang diimplementasikan oleh dewan direksi, manajemen serta seluruh staf dan karyawan dibawah arahan mereka dengan tujuan untuk memberikan jaminan yang memadai atas tercapainya tujuan pengendalian. Menurut Boynton (2002:370), pengendalian intern (internal control) adalah suatu proses yang dilaksanakan oleh dewan direksi, manajemen dan personel lainnya dalam suatu entitas yang dirancang untuk menyediakan keyakinan yang memadai berkenaan dengan pencapaian tujuan dalam kategori berikut: (1) keandalan laporan keuangan, (2) kepatuhan terhadap hukum dan peraturan yang berlaku, dan (3) efektivitas dan efesiensi operasi. Berdasarkan beberapa pengertian tersebut, maka dapat disimpulkan bahwa struktur pengendalian internal adalah serangkaian kebijakan dan prosedur yang telah diterapkan oleh sebuah perusahaan atau organisasi untuk dapat memberikan keyakinan yang memadai bahwa tujuan yang telah ditetapkan dapat tercapai.

COSO menyatakan bahwa pengendalian intern berada dalam proses manajemen dasar, yaitu perencanaan, pelaksanaan, dan monitoring. Pengendalian intern adalah suatu proses yang melibatkan seluruh anggota organisasi, dan 
memiliki tiga tujuan utama, yaitu efektivitas dan efisiensi operasi, mendorong kehandalan laporan keuangan, dan dipatuhinya hukum serta peraturan yang ada. Artinya, dengan adanya struktur pengendalian intern, maka perusahaan diharapkan dapat bekerja secara efektif dan efisien, penyajian informasi dapat diyakini kebenarannya dan semua pihak akan mematuhi semua peraturan yang ada, baik peraturan dan kebijakan perusahaan ataupun aturan legal / hukum pemerintah.

Kredit merupakan penyediaan uang atau tagihan yang dipersamakan dengan itu. Berdasarkan persetujuan kesepakatan pinjam meminjam antara pihak bank dengan pihak lain yang mewajibkan pihak peminjam untuk melunasi utangnya setelah jangka waktu dengan pemberian bunga (Martono, 2004:51).Rivai (2013:198) menyatakan kredit adalah penyerahan uang dari satu pihak (kreditur) atas dasar kepercayaan kepada pihak lain (debitur) dengan perjanjian pembayaran yang telah disepakati. Berdasarkan penjelasan di atas, dapat disimpulkan bahwa kredit merupakan suatu kegiatan penyediaan uang di mana telah terjadi kesepakatan pinjam meminjam antara kedua belah pihak, yang didasarkan pada kepercayaan untuk melunasi utangnya beserta jumlah bunga yang disepakati.

Lingkungan pengendalian merupakan dasar untuk semua komponen pengendalian internal yang membentuk kedisiplinan dan struktur. Lingkungan pengendalian mengarahkan organisasi dan memengaruhi kesadaran dari orangorang yang ada di dalam organisasi tersebut (Halim, 2008:212). Lingkungan pengendalian memiliki peran penting dalam penetapan tujuan, struktur 
organisasiyang jelas, dan penetapan wewenang dan tanggungjawab untuk setiap orang yang terlibat di dalam struktur organisasi.Lingkungan pengendalian pada LPD (Lembaga Perkreditan Desa) merupakan suatu gambaran mengenai sikap dan kesadaran secara menyeluruh dari pengurus, karyawan, dan pengawas mengenai pentingnya pengendalian internal organisasi LPD. Hal ini sejalan dengan teori keagenan yang mencerminkan tanggungjawab dari seluruh karyawan sesuai struktur organisasi yang ditetapkan. Penelitian yang dilakukan Haninun (2011), Adiari (2012), Ganic (2014), Isabella (2013), dan Akwaa (2016) menunjukkan bahwa variabel lingkungan pengendalian berpengaruh secara negatif pada non performing loan. Lingkungan pengendalian dapat tercermin dari struktur organisasi, semakin baik lingkungan pengendalian yang diterapkan, maka semakin rendah non performing loan.

H1 : Lingkungan pengendalian berpengaruh negatif pada non performing loan.

Penaksiran risiko adalah identifikasi, analisis, dan pengelolaan risiko yang relevan dengan penyusunan laporan keuangan yang disajikan secara wajar sesuai dengan prinsip akuntansi yang berlaku umum (Munawir, 2008:238). Risiko yang relevan mencakup peristiwa secara intern maupun ekstern yang dapat terjadi dan memengaruhi kemampuan entitas untuk mencatat, mengolah, meringkas, dan melaporkan data keuangan dalam laporan keuangan (Halim, 2008:213). Setiap organisasi harus dapat menilai risiko yang akan dihadapinya. Keberhasilan dalam mengenali risiko tersebut dipengaruhi oleh lingkungan pengendalian yang terbentuk. 
Penaksiran risiko LPD dapat tercermin dari penerapan pengendalian intern dalam pemberian kredit LPD di mana selalu dilakukan analisis terhadap kemampuan debitur untuk membayar kreditnya. Sejalan dengan teori keagenan yang tetap memperhatikan keuntungan antara pihak LPD dan debitur sesuai dengan perjanjian yang telah disepakati. Semakin tinggi penaksiran risiko yang dilakukan LPD, maka NPL atau kredit bermasalah akan semakin rendah. Pernyataan tersebut sejalan dengan penelitian yang dilakukan oleh Adiari (2012), Barrang (2011), Isabella (2013), Vazquez (2012), dan Akwaa (2016) menunjukkan bahwa variabel penaksiran risiko berpengaruh negatif pada non performing loan.

H2 : Penaksiran risiko berpengaruh negatif pada non performing loan.

Aktivitas pengendalian adalah kebijakan dan prosedur yang membantu menjamin bahwa arahan manajemen telah dilaksanakan (Halim, 2008:214). Pengendalian intern merupakan suatu kebijakan dan prosedur secara langsung maupun tidak langsung dapat meminimalkan kecurangan dan penyelewengan yang mungkin merugikan LPD. Aktivitas pengendalian LPD meliputi kegiatan otorisasi yang tepat dalam transaksi kredit dan pemisahan fungsi. Pemisahan fungsi harus dilakukan untuk mengurangi peluang seseorang dalam melakukan kecurangan atau kesalahan menjalankan tugas.

Hal ini sejalan dengan teori keagenan di mana dilakukan pemisahan fungsi untuk menghindari terjadinya konflik kepentingan. Dengan demikian, pihak LPD harus menjamin bahwa seluruh kegiatan transaksi tidak dikendalikan oleh 1 orang karyawan. Hal ini sejalan dengan hasil penelitian yang dilakukan oleh Isabella 
(2013), Zribi (2011), Virnawan (2014), dan Akwaa (2016) menunjukkan bahwa variabel aktivitas pengendalian berpengaruh negatif pada non performing loan.. Aktivitas pengendalian yang diterapkan dengan baik akan menurunkan nilai non performing loan.

H3: Aktivitas pengendalian berpengaruh negatif pada non performing loan.

Informasi dan komunikasi adalah pengidentifikasian dan pertukaran informasi dalam suatu bentuk dan waktu yang memungkinkan orang melaksanakan tanggung jawab mereka (Virnawan, 2014). Komunikasi meliputi penyediaan deskripsi tugas individu dan tanggung jawab yang berkaitan dengan struktur pengendalian internal (Halim, 2008:214). Menurut Munawir (2008:238) sistem informasi dan komunikasi yang relevan dengan tujuan pelaporan keuangan, yang memasukkan sistem akuntansi, terdiri dari metode-metode dan catatan yang diciptakan untuk mengidentifikasi, mengumpulkan, menganalisis, mengklasifikasi, mencatat, dan melaporkan transaksi-transaksi entitas.

Informasi dan komunikasi yang terjalin dalam LPD memungkinkan karyawan untuk memahami perannya dalam sistem pengendalian internal. Hal ini juga dilakukan untuk menjaga komunikasi dan koordinasi antara atasan dan bawahan. Sejalan dengan teori keagenan di mana hubungan antara atasan dan bawahan harus dilakukan dengan baik untuk menghindari adanya konflik kepentingan. Penelitian yang dilakukan oleh Haninun (2011),Barrang (2011), Ekaulandari (2013), Saraswati (2014), Isabella (2013), dan Akwaa (2016) menunjukkan bahwa variabel informasi dan komunikasi berpengaruh negatif pada kredit macet. 
H4: Informasi dan komunikasi berpengaruh negatif pada non performing loan.

Pemantauan adalah proses penilaian kualitas kinerja sistem pengendalian intern untuk menentukan apakah sistem pengendalian intern tersebut memerlukan perubahan karena terjadinya perubahan kondisi lingkungan. Pemantauan dilakukan untuk memberikan keyakinan apakah pengendalian internal telah dilakukan secara memadai atau tidak. Kegiatan pemantauan meliputi proses penilaian kualitas kinerja pengendalian internal sepanjang waktu, dan memastikan apakah semuanya dijalankan sesuai dengan tujuan.

Proses pemantauan dilakukan secara terjadwal dan dilakukan pengambilan tindakan yang tepat apabila kegiatan yang telah dijalankan tidak sesuai dengan kondisi yang terjadi. Hal ini sejalan dengan teori keagenan di mana selalu dilakukan pemantauan atau pengawasan untuk menghindari adanya konflik kepentingan antara pihak LPD dan debitur. Semakin baik pemantauan kredit yang dilakukan oleh LPD maka kredit bermasalah akan menurun. Penelitian yang dilakukan Haninun (2011), Adiari (2012), Isabella (2013) dan Akwaa (2016) menunjukkan bahwa variabel pemantauan berpengaruh negatif pada non performing loan.

H5: Pemantauan berpengaruh negatif pada non performing loan.

\section{METODE PENELITIAN}

Lokasi penelitian ini dilakukan pada Lembaga Perkreditan Desa (LPD) di Kota Denpasar. Alasan memilih lokasi penelitian tersebut karena Kota Denpasar merupakan Ibu Kota Provinsi Bali sekaligus sebagai pusat pemerintahan dan perekonomian Bali. Hal ini dilihat dari jumlah penduduk yang banyak dan 
perkembangan bisnisnya yang pesat, sehingga mencerminkan tingkat pertumbuhan ekonomi di Kota Denpasar.

Obyek penelitian merupakan obyek atau kegiatan yang memiliki kriteria yang telah ditetapkan oleh peneliti untuk dipelajari dan selanjutnya akan ditarik simpulannya (Sugiyono, 2017:102). Obyek penelitian dalam penelitian ini adalah non performing loan (Y) yang terjadi pada LPD di Kota Denpasar yang dipengaruhi oleh lingkungan pengendalian (X1), penaksiran risiko (X2), aktivitas pengendalian (X3), informasi dan komunikasi (X4), dan pemantauan (X5).

Berdasarkan data yang diperoleh dari Lembaga Pemberdayaan Lembaga Perkreditan Desa (LPLPD) Provinsi Bali, LPD yang masih beroperasi di Kota Denpasar sampai tahun 2017 sebanyak 35 LPD. Populasi dalam penelitian ini adalah seluruh LPD di Kota Denpasar yang berjumlah 35 LPD. Sampel adalah bagian dari jumlah dan karakteristik yang dimiliki oleh populasi sehingga dapat mewakili sifat-sifat populasi (Sugiyono, 2017:81). Penentuan sampel dalam penelitian ini adalah menggunakan sampel jenuh. Sampel jenuh berarti keseluruhan sampel akan dipilih sehingga dapat mencerminkan sifat populasinya.

Metode pengumpulan data yang digunakan dalam penelitian ini adalah kuesioner. Kuesioner yaitu metode pengumpulan data yang dilakukan dengan cara memberi seperangkat pertanyaan atau pernyataan tertulis kepada responden untuk dijawab (Sugiyono, 2017:142). Dalam penelitian ini pernyataan yang disebarkan mengenai lingkungan pengendalian, penaksiran risiko, aktivitas pengendalian, informasi dan komunikasi, dan pemantauan. 
Jumlah responden yang digunakan dalam penelitian ini sebanyak 105 orang yang terdiri dari 3 orang di dalam satu LPD yaitu pengawas internal LPD, kepala LPD dan karyawan pada bagian kredit. Dipilihnya pengawas internal LPD, kepala LPD dan karyawan bagian kredit sebagai responden karena mengetahui dan mendalami mengenai tugas, wewenang dalam aktivitas perkreditan dan pengelolaan LPD.

Analisis regresi linier berganda merupakan analisis yang digunakan untuk mengetahui hubungan dan pengaruh variabel-variabel bebas (independen) terhadap variable terikat (dependen). Analisis regresi merupakan suatu metode yang digunakan untuk menganalisis hubungan antar variabel (Sugiyono, 2017:192).

$$
Y=\alpha+\beta_{1} X_{1}+\beta_{2} X_{2}+\beta_{3} X_{3}+\beta_{4} X_{4}+\beta_{5} X_{5} \varepsilon_{i}
$$

Keterangan:

$$
\begin{array}{ll}
\mathrm{Y} & =\text { Non Performing Loan } \\
\alpha & =\text { Konstanta } \\
\beta_{1}-\beta_{5} & =\text { Koefisien regresi } \\
\mathrm{X}_{1} & =\text { Lingkungan Pengendalian } \\
\mathrm{X}_{2} & =\text { Penaksiran Risiko } \\
\mathrm{X}_{3} & =\text { Aktivitas Pengendalian } \\
\mathrm{X}_{4} & =\text { Informasi dan Komunikasi } \\
\mathrm{X}_{5} & =\text { Pemantauan } \\
\mathrm{e} & =\text { Error }
\end{array}
$$

\section{HASIL PENELITIAN DAN PEMBAHASAN}

Statistik deskriptif adalah statistik yang digunakan untuk menganalisa data dengan cara mendeskripsikan atau menggambarkan data yang telah terkumpul sebagaimana adanya tanpa bermaksud membuat kesimpulan yang berlaku untuk umum atau generalisasi (Sugiyono, 2017:287). Hasil statistik deskriptif penelitian ini dapat dilihat pada Tabel 1. sebagai berikut. 
Tabel 1.

Hasil Statistik Deskriptif

\begin{tabular}{lcrrrr}
\hline \multicolumn{1}{c}{ Variabel } & N & Min. & Max & Mean & $\begin{array}{c}\text { Standard } \\
\text { Deviasi }\end{array}$ \\
\hline Non Performing Loan $(\mathrm{Y})$ & 96 & 0,38 & 31,16 & 11,33 & 7,81679 \\
Lingkungan Pengendalian $\left(\mathrm{X}_{1}\right)$ & 96 & 2,56 & 4,00 & 3,57 & 0,37985 \\
Penaksiran Risiko $\left(\mathrm{X}_{2}\right)$ & 96 & 2,83 & 4,00 & 3,50 & 0,37329 \\
Aktivitas Pengendalian $\left(\mathrm{X}_{3}\right)$ & 96 & 2,33 & 4,00 & 3,52 & 0,43009 \\
Informasi dan Komunikasi (X4) & 96 & 2,75 & 4,00 & 3,57 & 0,41218 \\
Pemantauan (X5) & 96 & 2,67 & 4,00 & 3,46 & 0,38129 \\
\hline
\end{tabular}

Sumber: Data diolah, 2018

Berdasarkan Tabel 1 dapat disimpulkan bahwa jumlah pengamatan $(\mathrm{N})$ dalam penelitian ini adalah 96. Variabel Non Performing Loan memiliki nilai minimum sebesar 0,38 persen dan nilai maksimum sebesar 31,16 persen. Ratarata variabel Non Performing Loan sebesar 11,33 persen. Standar deviasi pada variabel Non Performing Loan sebesar 7,81 persen. Hal ini menunjukkan bahwa standar penyimpangan data terhadap nilai rata-ratanya adalah sebesar 7,81 persen.

Variabel lingkungan pengendalian memiliki nilai minimum sebesar 2,56 dan nilai maksimum sebesar 4,00 dengan nilai rata-rata sebesar 3,57. Nilai ratarata sebesar 3,57 menunjukkan bahwa respon responden dalam menjawab pernyataan kuesioner cenderung setuju, yang berarti lingkungan pengendalian berkaitan non performing loan. Standar deviasi pada variabel lingkungan pengendalian adalah sebesar 0,37. Hal ini menunjukkan bahwa standar penyimpangan data terhadap nilai rata-ratanya adalah sebesar 0,37 .

Variabel penaksiran risiko memiliki nilai minimum sebesar 2,83 dan nilai maksimum sebesar 4,00 dengan nilai rata-rata sebesar 3,50. Nilai rata-rata sebesar 3,50menunjukkan bahwa respon responden dalam menjawab pernyataan kuesioner cenderung sangat setuju, yang berarti bahwa penaksiran risiko berkaitan dengan non performing loan. Standar deviasi pada variabel penaksiran risiko 
adalah sebesar 0,37. Hal ini menunjukkan bahwa standar penyimpangan data terhadap nilai rata-ratanya adalah sebesar 0,37 .

Variabel aktivitas pengendalian memiliki nilai minimum sebesar 2,33 dan nilai maksimum sebesar 4,00 dengan nilai rata-rata sebesar 3,52. Nilai rata-rata sebesar 3,52menunjukkan bahwa respon responden dalam menjawab pernyataan kuesioner cenderung sangat setuju, yang berarti bahwa aktivitas pengendalian berkaitan dengan non performing loan. Standar deviasi pada variabel aktivitas pengendalian adalah sebesar 0,43. Hal ini menunjukkan bahwa standar penyimpangan data terhadap nilai rata-ratanya adalah sebesar 0,43 .

Variabel informasi dan komunikasi memiliki nilai minimum sebesar 2,75 dan nilai maksimum sebesar 4,00 dengan nilai rata-rata sebesar 3,57. Nilai ratarata sebesar 3,57menunjukkan bahwa respon responden dalam menjawab pernyataan kuesioner cenderung sangat setuju, yang berarti bahwa informasi dan komunikasi berkaitan dengan non performing loan. Standar deviasi pada variabel informasi dan komunikasi adalah sebesar 0,41. Hal ini menunjukkan bahwa standar penyimpangan data terhadap nilai rata-ratanya adalah sebesar 0,41.

Variabel pemantauan memiliki nilai minimum sebesar 2,67 dan nilai maksimum sebesar 4,00 dengan nilai rata-rata sebesar 3,46. Nilai rata-rata sebesar 3,46menunjukkan bahwa respon responden dalam menjawab pernyataan kuesioner cenderung sangat setuju, yang berarti bahwa pemantauan berkaitan dengan non performing loan. Standar deviasi pada variabel pemantauan adalah sebesar 0,38. Hal ini menunjukkan standar penyimpangan data terhadap nilai rataratanya adalah 0,38 . 
Analisis regresi linier berganda digunakan untuk mengetahui hubungan dan pengaruh variabel bebas terhadap variabel terikat. Regresi linier berganda mampu menjelaskan pengaruh pengendalian internal terhadap non performing loan pada LPD di Kota Denpasar. Hasil pengujian analisis regresi linier berganda dapat dilihat pada Tabel 2. berikut.

Tabel 2.

Hasil Uji Regresi Linier Berganda

\begin{tabular}{lccccc}
\hline \multicolumn{1}{c}{ Model } & \multicolumn{2}{c}{$\begin{array}{c}\text { Unstandardized } \\
\text { Coefficients }\end{array}$} & $\begin{array}{c}\text { Standardized } \\
\text { Coefficients }\end{array}$ & T & Sig. \\
& B & Std. Error & Beta & & \\
\hline (Constant) & 34,749 & 8,141 & & 4,269 & 0,000 \\
Lingkungan Pengendalian & $-0,428$ & 0,385 & $-0,187$ & $-1,111$ & 0,030 \\
Penaksiran Risiko & $-0,958$ & 0,637 & $-0,275$ & $-1,504$ & 0,036 \\
Aktivitas Pengendalian & $-0,056$ & 0,485 & $-0,019$ & $-0,116$ & 0,008 \\
Informasi dan Komunikasi & 0,788 & 0,742 & 0,166 & 1,062 & 0,091 \\
Pemantauan & $-0,095$ & 0,539 & $-0,028$ & $-0,176$ & 0,006 \\
R Square & & & 0,520 & & \\
Signifikansi F & & & 0,040 & & \\
F Hitung & & & 2,446 & &
\end{tabular}

Berdasarkan Tabel 2 analisis regresi linier berganda terhadap varibel bebas dan variabel terikat diperoleh hasil koefisien $\alpha=34,749$ dan nilai koefision $\beta 1=-0,428, \beta 2=-0,958, \beta 3=-0,056, \beta 4=0,788, \beta 5=-0,095$. Berdasarkan hasil penelitian, maka model persamaan regresi linier berganda tampak sebagai berikut:

$$
\mathrm{Y}=34,749-0,428 \mathrm{X}_{1}-0,958 \mathrm{X}_{2}-0,056 \mathrm{X}_{3}+0,788 \mathrm{X}_{4}-0,095 \mathrm{X}_{5}
$$

Berdasarkan hasil uji koefisien determinasi pada Tabel 2 menunjukkan bahwa koefisien determinasi ( $\mathrm{R}$ Square)sebesar 0,520 atau 52 persen, angka ini dapat diartikan bahwa 52 persen tingkat non performing loan mampu dijelaskan oleh variabel pengendalian intern yang meliputi lingkungan pengendalian, penaksiran risiko, aktivitas pengendalian, informasi dan komunikasi, dan 
pemantauan, sedangkan sisanya 48 persen dijelaskan oleh variabel lain diluar model regresi yang digunakan.

Berdasarkan hasil perhitungan uji $\mathrm{F}$ pada Tabel 2, diperoleh tingkat signifikansi sebesar 0,040 yang lebih kecil dari $\alpha=0,05$, maka model regresi yang digunakan dianggap layak untuk digunakan.Berdasarkan hasil perhitungan pada Tabel 2 diperoleh nilai signifikansi uji t untuk lingkungan pengendalian sebesar 0,030 lebih kecil dari $\alpha=0,05$ dan nilai koefisien regresi sebesar $-0,428$. Hal ini berarti bahwa lingkungan pengendalian berpengaruh negatif pada non performing loan. Dengan demikian hipotesis pertama $\left(\mathrm{H}_{1}\right)$ diterima. Adanya pengaruh signifikan variabel lingkungan pengendalian dan non performing loan mengandung arti bahwa semakin baik lingkungan pengendalian yang diterapkan, makaakan menurunkan tingkat kredit bermasalah. Lingkungan pengendalian LPD dapat tercermin dari penerapan struktur organisasi LPD yang jelas, kesadaran karyawan LPD terhadap tugas dan tanggungjawabnya. Pengurus dan karyawan LPD juga telah menjalankan kegiatan operasional dengan baik sehingga pengendalian intern terutama pada pemberian kredit dapat berjalan secara efektif dan tingkat rasio non performing loan.

Lingkungan pengendalian berperan dalam penetapan tujuan dan struktur organisasi yang jelas, sehingga tugas dan tanggungjawab dijalankan sesuai dengan prosedur (Trisnadewi, 2018). Hasil penelitian ini sesuai dengan penelitian yang dilakukan oleh Ekaulandari (2013), Saraswati (2014), Herawati (2014), Akwaa (2016) dan Trisnadewi (2018) yang menyatakan bahwa lingkungan pengendalian berpengaruh negatif pada non performing loan. Lingkungan pengendalian LPD 
yang efektif mencerminkan pembagian tugas yang efektif juga. Hasil penelitian ini juga sejalan dengan teori keagenan di mana teori ini mencerminkan tugas dan tanggungjawab yang jelas dari masing-masing karyawan sesuai dengan struktur organisasi yang telah ditetapkan. Penetapan tugas dan tanggungjawab ini akanberpengaruh terhadap kelangsungan usaha, di mana masing-masing karyawan harus fokus pada tugas dan tanggungjawabnya, sehingga dapat menurunkan non performing loan.

Berdasarkan hasil perhitungan pada Tabel 2 diperoleh nilai signifikansi uji $\mathrm{t}$ untuk penaksiran risiko sebesar 0,036 lebih kecil dari $\alpha=0,05$ dan nilai koefisien regresi sebesar -0,958. Hal ini berarti bahwa penaksiran risiko berpengaruh negatif pada non performing loan. Dengan demikian hipotesis kedua $\left(\mathrm{H}_{2}\right)$ diterima. Adanya pengaruh signifikan variabel penaksiran risiko dan non performing loan mengandung arti bahwa proses identifikasi terhadap risiko-risiko yang akan terjadi telah dilakukan dengan baik, sehingga baik pengendalian risiko kredit macet (Smith, 2012). Penaksiran risiko LPD dapat tercermin dari penerapan pengendalian intern dalam pemberian kredit LPD di mana selalu dilakukan analisis terhadap kemampuan debitur untuk membayar kreditnya.

Hasil penelitian ini sesuai dengan hasil penelitian Sabi (2013), Depitasari (2014), dan Akwaa (2016) yang menyatakan bahwa penaksiran risiko berpengaruh negatif pada kredit bermasalah. Penaksiran risiko dapat ditingkatkan dengan melaksanakan proses analisis yang matang dalam memberikan kredit untuk mengurangi NPL. Hasil penelitian ini sejalan dengan teori keagenan di mana pihak LPD menyalurkan dana dalam bentuk kredit kepada debitur untuk 
dikelola sesuai dengan kepentingan debitur dan debitur harus dapat mengembalikan kredit tersebut kepada pihak LPD. Teori ini dapat terwujud dalam kontrak yang mengatur hak dan kewajiban dengan tetap memperhatikan keuntungan masing-masing pihak. Kontrak ini akan optimal apabila agen (debitur) menjalankan kewajibannya yaitu membayar kredit kepada principal (pihak LPD) sesuai dengan perjanjian yang telah disepakati.

Berdasarkan hasil perhitungan pada Tabel 2 diperoleh nilai signifikansi uji $\mathrm{t}$ untuk variabel aktivitas pengendalian sebesar 0,008 lebih kecil dari $\alpha=0,05$ dan nilai koefisien regresi sebesar $-0,056$. Hal ini berarti bahwa aktivitas pengendalian berpengaruh negatif pada non performing loan. Dengan demikian hipotesis ketiga $\left(\mathrm{H}_{3}\right)$ diterima. Aktivitas pengendalian bernilai negatif berarti bahwa semakin tinggi penerapan aktivitas pengendalian maka kredit bermasalah atau non performing loan akan semakin rendah. Aktivitas pengendalian LPD tercermin dari kegiatan operasional LPD dan sistem pemberian kredit LPD yang telah dilaksanakan sesuai dengan prosedur yang diterapkan. Aktivitas pengendalian LPD juga meliputi kegiatan otorisasi yang tepat dalam transaksi kredit dan pemisahan tugas LPD. Pemisahan tugas LPD dilakukan untuk mengurangi peluang seseorang dalam melakukan kecurangan atau kesalahan menjalankan tugas serta menurunkan tingkat non performing loan LPD.

Hasil penelitian ini sejalan dengan hasil penelitian Adiari (2012), Hasanuddin (2015), Agustina (2016), dan Akwaa (2016) yang menyatakan bahwa aktivitas pengendalian berpengaruh negatif pada non performing loan.Hasil penelitian ini juga sesuai dengan teori agensi di mana dalam pengelolaan suatu 
lembaga keuangan harus dilakukan pemisahan tugas untuk menghindari terjadinya konflik kepentingan akibat ketidaksamaan tujuan dan menjadi peluang dalam melakukan berbagai kecurangan. Dengan demikian, aktivitas pengendalian yang diterapkan dengan baik akan mengurangi tingkat kredit bermasalah.

Berdasarkan hasil perhitungan pada Tabel 2 diperoleh nilai signifikansi uji $\mathrm{t}$ untuk variabel informasi dan komunikasi sebesar 0,091 lebih besar dari $\alpha=0,05$ dan nilai koefisien regresi sebesar 0,788 . Hal ini berarti bahwa informasi dan komunikasi tidak berpengaruh pada non performing loan. Dengan demikian hipotesis keempat $\left(\mathrm{H}_{4}\right)$ ditolak. Informasi dan komunikasi LPD dapat tercermin dari proses pembukuan dan penyampaian informasi kepada karyawan LPD. Dalam hal ini proses pembukuan dan penyampaian informasi yang dilakukan LPD tidak memengaruhi besar kecilnya tingkat non performing loan. Informasi dan komunikasi LPD yang baik seharusnya tercermin dari komunikasi antara atasan dan bawahan atau koordinasi dari bawahan ke atasan. Komunikasi yang baik seharusnya diterapkan pada LPD sehingga memberikan keyakinan bahwa transaksi telah dicatat, telah diotorisasi dan telah dinilai dengan wajar sehingga dapat menekan kredit macet.

Informasi merupakan pertukaran berita atau data dalam suatu waktu yang memungkinkan orang melaksanakan tanggungjawabnya. Penelitian ini sejalan dengan penelitian yang dilakukan oleh Putra (2014) dan Gunadi (2017) yang menyatakan bahwa informasi dan komunikasi tidak berpengaruh pada non performing loan. Semakin baik penerapan informasi dan komunikasi dalam LPD tidak memengaruhi besar kecilnya tingkat kredit macet yang terjadi pada LPD. 
Berdasarkan hasil perhitungan pada Tabel 2 diperoleh nilai signifikansi uji t untuk variabel pemantauan sebesar 0,006 lebih kecil dari $\alpha=0,05$ dan nilai koefisien regresi sebesar -0,095. Hal ini berarti bahwa pemantauan berpengaruh negatif pada non performing loan. Dengan demikian hipotesis kelima $\left(\mathrm{H}_{5}\right)$ diterima. Pemantauan merupakan hal yang terpenting dalam pengendalian intern pemberian kredit. Pemantauan bernilai negatif yang berarti bahwa pemantauan yang dilakukan secara rutin akan menurunkan tingkat kredit bermasalah LPD. Pemantauan dalam LPD meliputi proses penilaian kualitas kinerja sepanjang waktu, dan memastikan semuanya dijalankan seperti yang diinginkan dan disesuaikan dengan perubahan keadaan. Hal ini berarti bahwa semakin rutin pihak LPD dalam melakukan pemantauan atau pengawasan maka semakin rendah tingkat kredit bermasalah.Pemantauan dilakukan untuk memberikan keyakinan apakah pengendalian internal telah dilakukan secara efektif atau tidak. Hasil penelitian ini sesuai dengan penelitian Adiari (2012), Isabella (2013), Hasanuddin (2015), dan Akwaa (2016) yang menyatakan pemantauan berpengaruh negatif pada non performing loan. Pemantauan yang dilakukan dengan baik dapat menurunkan non performing loan.

Hasil penelitian ini memberikan tambahan informasi mengenai pengaruh lingkungan pengendalian, penaksiran risiko, aktivitas pengendalian, informasi dan komunikasi, dan pemantauan pada non performing loan. Bukti empiris yang diperoleh melalui penelitian ini yang menunjukkan bahwa lingkungan pengendalian berpengaruh negatif pada non performing loan, penaksiran risiko berpengaruh negatif pada non performing loan, aktivitas pengendalian 
berpengaruh negatif pada non performing loan, informasi dan komunikasi tidak memiliki pengaruh pada non performing loan, dan pemantauan berpengaruh negatif pada non performing loan. Penelitian ini menunjukkan semakin baik lingkungan pengendalian dan penaksiran risiko yang diterapkan maka non performing loan akan menurun. Aktivitas pengendalian dan pemantauan yang semakin rutin akanmenurunkan tingkat terjadinya non performing loan. Hal ini didukung dengan adanya teori agensi menyatakan bahwa dalam suatu lembaga keuangan dibatasi oleh kontrak yang menyebutkan bahwa lembaga keuangan dalam hal ini pihak LPD sepakat untuk memberikan kredit kepada debitur agar LPD memperoleh penerimaan laba demi menjamin kelangsungan usahanya.

Hasil penelitian ini dapat memberikan informasi bagi semua pihak yang berkaitan dengan struktur pengendalian intern pada non performing loan. Bahan pertimbangan dan masukan bagi kepala LPD agar meningkatkan struktur pengendalian intern untuk meminimalisir terjadinya kredit bermasalah. Bahan pertimbangan juga bagi Lembaga Pemberdayaan LPD (LPLPD) agar memperkuat pemberdayaan bagi LPD mengenai pengendalian kredit bermasalah.

\section{SIMPULAN}

Berdasarkan hasil analisis data dan pembahasan yang telah diuraikan diatas, maka dapat ditarik kesimpulan bahwa variabel lingkungan pengendalian berpengaruh negatif pada non performing loan di LPD Kota Denpasar. Hal ini menunjukkan bahwa semakin baik lingkungan pengendalian yang diterapkan maka semakin baik kesadaran karyawan dalam menurunkan non performimg loan.Variabel penaksiran risiko berpengaruh negatif pada non performing loan di LPD Kota 
Denpasar. Hal ini menunjukkan bahwa semakin baik tahapan analisis, identifikasi dan pengelolaan risiko yang dilakukan akan semakin baik dan menurunkan tingkat non performing loan.Variabel aktivitas pengendalian berpengaruh negatif pada non performing loan di LPD Kota Denpasar. Hal ini menunjukkan bahwa aktivitas pengendalian yang dilakukan secara maksimal akanmengurangi tingkat non performing loan. Variabel informasi dan komunikasi tidak berpengaruh pada non perfoming loan di LPD Kota Denpasar. Hal ini menunjukkan bahwa informasi dan komunikasi yang terjalin dalam LPD tidak memengaruhi besar kecilnya tingkat non performing loan. Variabel pemantauan berpengaruh negatif pada non performing loan di LPD Kota Denpasar. Hal ini menunjukkan bahwa pemantauan atau pengawasan yang dilakukan secara rutin akan mengurangi risiko terjadinya non performing loan.

Berdasarkan simpulan di atas, maka saran yang dapat diberikan adalah penelitian ini dapat membuktikan bahwa lingkungan pengendalian, penaksiran risiko, aktivitas pengendalian dan pemantauan berpengaruh pada non performing loan, maka saran yang dapat diberikan peneliti untuk LPD, pihak LPD diharapkan dapat meningkatkan struktur pengendalian intern dalam hal pemberian kredit dan mempertahankan proses analisis risiko, identifikasi risiko dan pemisahan fungsi untuk mengurangi terjadinya kecurangan dalam merealisasikan kredit sehingga kedepannya dapat meningkatkan profitabilitas LPD dan menurunkan tingkat non performing loan.

Penelitian ini diharapkan dapat dijadikan pertimbangan oleh penelitian selanjutnya dengan menambahkan variabel loan to deposit ratio untuk dapat 
menilai besarnya penyaluran kredit pada kredit bermasalah dan lingkungan pengendalian sebagai moderasi, karena lingkungan pengendalian merupakan dasar untuk semua komponen pengendalian intern. Bagi peneliti selanjutnya disarankan untuk dapat memperoleh sampel yang lebih banyak agar hasil yang diperoleh lebih representatif serta meningkatkan kualitas data.

\section{REFERENSI}

Agustina, Gita Putri. 2016. Faktor-Faktor yang Mempengaruhi Kelemahan Pengendalian Intern Pemerintah Daerah. Jurnal Ilmu dan Riset Akuntansi STIESIA Surabaya. 5(4).

Akwaa Ellis K, 2016. Effect of Internal Controls on Credit Risk among Listed Spanish Banks. Omnia Science. Journal of Scientific Information System, Vol 12. No.1: 357-389. http://dx.doi.org/10.3926/ic.703. Diunduh pada 18 Januari 2018.

Ambaroita, Martha Novalina. 2015. Faktor-Faktor Yang Mempengaruhi Loan to Deposit Ratio (LDR) Bank Umum Di Indonesia Periode 2009. Journal of Economics Development Analysis.

Boynton, Johnson, dan Kell. 2003. Modern Auditing. Edisi Ketujuh, Buku Dua. Jakarta: Erlangga.

Depitasari. 2014. Pengaruh Lingkungan Pengendalian Internal Terhadap Kualitas Informasi Laporan Kuangan Pada Dinas Pendapatan Daerah Provinsi Sumatera Selatan. Jurnal Akuntansi STIE Palembang.

Diana, Anastasia dan Setiawati, Lilis. 2011. Sistem Informasi Akuntansi, Perancangan, Proses, dan Penerapan. Edisi 1. Yogyakarta: Andi Yogyakarta.

Ekaulandari, Ni Wayan Vany. 2013. Pengaruh Penaksiran Risiko, Informasi dan Komunikasi, Aktivitas Pengendalian, Pemantauan, Lingkungan Pengendalian Pada Efektivitas Sistem Pemberian Kredit. Jurnal Akuntansi Universitas Udayana, 13(1): 585-604.

Ganic, M. 2014. Bank Specific Determinants of Credit Risk: an Empirical Study on the Banking Sector of Bosnia and Herzegovina. Journal of Economic Practices and Theories. 4(4): 428-436. 
Ghazwani, Ines. 2016. Explanatory Factors of Credit Risk: Empirical Evidence From Tunisian Banks. Journal or Economics, Finance, and Management. 5(1).

Gunadi, I G. Ngurah Bagus. 2017. Efisiensi Penyaluran Kredit Pada Lembaga Perkreditan Desa: Kajian Berdasarkan Komponen Struktur Pengendalian Intern. Jurnal Fakultas Ekonomi Universitas Mahasaraswati.

Halim, Abdul. 2008. Auditing 1 (Dasar-dasar Audit Laporan Keuangan). Edisi Kedua. Semarang: Universitas Diponegoro

Haninun. 2011. Pengaruh Pengendalian Intern Perkreditan Terhadap Kredit Bermasalah pada PT. Bank Rakyat Indonesia (Persero) Tbk. Cabang Teluk Betung. Jurnal Akuntansi dan Keuangan. 2(1): 143-164.

Harmadji, Dwi Ekasari. 2016. Internal Control in Perspective of Personal Bankers. European Journal of Business and Management. 8(2).

Hasibuan, Malayu S.P. 2008. Dasar-dasar Perbankan. Edisi Ketiga. Jakarta : PT Bumi Aksara.

Herawati, Tuti. 2014. Pengaruh Sistem Pengendalian Intern Terhadap Kualitas Laporan Keuangan (Survei Pada Organisasi Perangkat Daerah Pemda Cianjur). Study \& Accounting Research.11(1).

Isabella. 2013. Pengaruh Pengendalian Internal Terhadap Kredit Macet (Studi Kasus Pada Finance di Kota Palembang). Jurnal Akuntansi STIE Multi Data Palembang.

Janvrin, Diane J., Payne, Byrnes, P., Schneider, GP., Curtis, MB. 2012. The Updated COSO Internal Control Integrated Framework : Recommendations and Opportunities for Future Research. Journal of Information Systems. http://search.proquest.com. Diunduh pada 18 Desember 2017.

Lelly, Cecilia. 2017. The Influence of Internal Control Implementation and Managerial Performance on Financial Accountability Local Goverment in Indonesia. Journal of Economics and Financial. 7(1): 293-297.

Lembaga Pemberdayaan Lembaga Perkreditan Desa (LPLPD) Provinsi Bali. 2018

Leonny Ariesa and Ruben Garcia. 2009. The Analysis Of Internal Controls On Revenue And Expenditure Cycle In PT. Levina. Journal of applied Finance and Accounting Binus University. 
Maharani, Putri Oceana. 2014. Pengaruh Efektivitas Struktur Pengendalian Intern Terhadap Kinerja Perkreditan Pada Bank Perkreditan Rakyat di Kota Denpasar. Jurnal Akuntansi Universitas Udayana, 6(1): 95-104.

Martono dan Harjito, Agus. 2004. Manajemen Keuangan. Yogyakarta: Ekonisia.

Mihaela, Dumitrascu and Savulescu Iulian. 2012. Internal Control and the Impact on Corporate Governance, in Romanian Listed Companies. Journal of Business \& Economics Studies Romania.

Mulyadi. 2010. Auditing. Edisi keenam. Jakarta: Salemba Empat

Munawir, H.S. 2008. Auditing Modern Buku 1 Edisi 2. Yogyakarta: BPFE Yogyakarta

Murtanto. 2005. Sistem Pengendalian Internal Kas. Jakarta: PT Hecca Mitra Utama.

Peraturan Gubernur Bali Nomor 44 Tahun 2017 tentang Peraturan Pelaksanaan Peraturan Daerah Provinsi Bali Nomor 3 Tahun 2017 tentang Lembaga Perkreditan Desa.

Pratama, Billy Arma. 2010. Analisis Faktor - Faktor yang Mempengaruhi Kebijakan Penyaluran Kredit Perbankan. Tesis. Universitas Diponogoro.

Putra, I Gede Cahyadi. 2014. The Influence of The Component of Internal Control Structure on Credit Provision Efficiency on Local Credit Institutions (LPD) in Denpasar. Journal Universitas Surabaya.

Rivai, dan Veithzal, A.P. 2013. Credit Management Handbook. Jakarta: PT. Raja Grafindo Persada.

Saraswati, Lukyta. 2014. Pengaruh Struktur Pengendalian Intern terhadap Kelancaran Pengembalian Kredit pada Koperasi Simpan Pinjam di Kota Denpasar. Jurnal Akuntansi Universitas Udayana, 14(1): 122-134.

Smith, Hermansor, D.R., and Stephens. 2012. How Effective are Organization's Internal Control. Journal. $26 \quad$ (2). http://site.ebrary.com/lib/unud. Diunduh pada 19 Desember 2017.

Sugiyono. 2017. Metode Penelitian Kuantitatif, kualitatif, dan R\&D. Bandung: Alfabeta.

Trisnadewi, A. A. Ayu Erna, 2018. Pengaruh Pengendalian Intern Terhadap Efektivitas Penyaluran Kredit Pada Lembaga Perkreditan Desa (LPD) di 
Kecamatan Abiansemal Kabupaten Badung. Jurnal Riset Akuntansi Fakultas Ekonomi Universitas Warmadewa. 9 (2).

Vazquez, F., B.M. Tabak and M. Sauto. 2012. A Macro Stress Test Model of Credit Risk for the Brazilian Banking Sector.Journal of financing stability8(1): 69-83.

Virnawan, I Made Elly dan Putra, I Gede Cahyadi. 2014. Efisiensi Penyaluran Kredit Pada Lembaga Perkreditan Desa (LPD) di Kecamatan MargaTabanan. Jurnal Akuntansi Universitas Udayana. 9 (2).

Yasa, I Desa Putu Gede Sumerta dan Jati, I Ketut. 2013. Pengaruh Komponen Pengendalian Internal Kredit Bermasalah BPR di Kabupaten Buleleng. Jurnal Akuntansi Universitas Udayana. 4 (2): 315-331.

Zribi, N. and B. Younes. 2011. The factors influencing bank credit risk: The case of Tunisia. Journal of accounting and taxation 3 (4): 70-78. 